\title{
GENERALIZATION OF MAJORIZATION THEOREM VIA TAYLOR'S FORMULA
}

\section{SAAD IHSAN BUTT, LJILJANKA KVESIĆ AND JOSIP PEČARIĆ}

Abstract. We give generalization of majorization theorem for the class of $\mathrm{n}$-convex functions by using Taylor's formula. We use inequalities for the Čebyšev functional to obtain bounds for the identities related to generalizations of majorization inequalities. We present mean value theorems and $n$-exponential convexity for the functional obtained from the generalized majorization inequalities. At the end we discuss the results for particular families of function and give means.

Mathematics subject classification (2010): Primary 26D07, 26D15, 26D20, 26 D99.

Keywords and phrases: Convex function, divided difference, Taylor's formula, Čebyšev functional, Grüss inequality, Ostrowski inequality, exponential convexity.

\section{REFERENCES}

[1] N. S. BARnett, P. Cerone And S. S. Dragomir Majorisation inequalities for Stieltjes integrals, Appl. Math. Lett. 22 (2009), 416-421.

[2] S. N. Bernstein, Sur les fonctions absolument monotones, Acta Math. 52 (1929), 1-66.

[3] S. I. ButT And J. PeČArić, Generalized Hermite-Hadamard's Inequality, Proc. A. Razmadze Math. Inst. 163 (2013), 9-27.

[4] S. I. Butt, K. A. Khan And J. PeČArić, Popoviciu type inequalities Via Green function and generalized Montgomery identity, Math. Inequal. Appl. 18 (4) (2015), 1519-1538.

[5] P. CERONE AND S. S. DRAGOMIR, Some new Ostrowski-type bounds for the Čebyšev functional and applications, J. Math. Inequal. 8 (1) (2014), 159-170.

[6] L. FUCHS, A new proof of an inequality of Hardy-Littlewood-Polya, Mat. Tidsskr. B (1947), 53-54.

[7] J. JAKŠETIC AND J. PeČARIĆ, Exponential Convexity Method, J. Convex Anal. 20 (1) (2013), 181 197.

[8] J. JAKŠEtić, J. PeČARIĆ AND A. Perušić, Steffensen inequality, higher order convexity and exponential convexity, Rend. Circ. Mat. Palermo. 63 (1) (2014), 109-127.

[9] M. Adil Khan, NAVEed Latif AND J. PeČARIĆ, Generalization of majorization theorem, J. Math. Inequal. 9 (3) (2015), 847-872.

[10] N. Latif, J. PeČArić And I. Perić, On Majorization, Favard and Berwald's Inequalities, Ann. Funct. Anal. 2 (2011), 31-50.

[11] A. W. MARshall, I. OlKin AND BARry C. ARnold, Inequalities: Theory of Majorization and Its Applications (Second Edition), Springer Series in Statistics, New York (2011).

[12] L. Maligranda, J. PeČArić And L. E. Persson, Weighted Favard's and Berwald's Inequalities, J. Math. Anal. Appl. 190 (1995), 248-262.

[13] J. PEČARIĆ, On some inequalities for functions with nondecrasing increments, J. Math. Anal. Appl. 98 (1984), 188-197.

[14] J. PeČARIĆ And J. Perić, Improvement of the Giaccardi and the Petrović Inequality and Related Stolarsky Type Means, An. Univ. Craiova Ser. Mat. Inform. 39 (1) (2012), 65-75.

[15] J. Pečarić, F. Proschan and Y. L. Tong, Convex functions, Partial Orderings and Statistical Applications, Academic Press, New York, (1992). 